УДК: 351

DOI: https://doi.org/10.32689/2618-0065-2020-2(4)-258-271

Мурашко Віталій Сергійович, старший викладач кафедри публічного адміністрування, аспірант, Міжрегіональна Академія управління персоналом, 03039, м. Київ, вул. Фрометівська, 2, тел.: 06349531 43, e-mail: murashko.vitalii1981@gmail.com, https//orcid.org/0000-0002-8668-2043

\title{
КЛЮЧОВІ НАПРЯМИ ТРАНСФОРМАЦІї МІСІЇ УКРАЇНИ У ФОРМУВАННІ АРХІТЕКТУРИ СУЧАСНОЇ СИСТЕМИ ЗАБЕЗПЕЧЕННЯ СВРОПЕЙСЬКОЇ БЕЗПЕКИ
}

Анотація: Стаття присвячена формуванню переліку ключових напрямів трансформації місії України у реалізації архітектури сучасної системи забезпечення європейської безпеки. До проблематики зазначеного питання суміжно та побіжно звертали свої наукові пошуки як державні управлінці, так і вчені інших галузевих наук. Однак, безпосередньо, дане питання вони не вивчали, що свідчить про його сучасну актуалізацію.

Визначено, що Україна має дуже мало шансів повноцінно увійти у європейське співтовариство без якісних та суттєвих змін у внутрішньому політичному та правовому полях. Також, необхідні зміни у вітчизняному законодавстві з питань створення ефективних механізмів протидії корупції, розробки радикальної реформи безпеки, військової системи тощо. Проведене дослідження дає підстави стверджувати, що відновити обороноздатність держави за короткий термін практично неможливо, оскільки, це тривалий процес, який потребує значних інвестицій та часу.

Слід розуміти, що військову безпеку та оборону можна посилити, беручи участь у роботі міжнародних організацій колективної безпеки. Зважаючи на це, у сфері безпеки та оборонної політики курс на європейську інтеграцію Україна розпочала з підписання 13 червня 2005 р. Угоди між Європейським Союзом і Україною про визначення загальної схеми участі України в операціях Європейського Союзу із врегулювання криз, що ратифікована Законом України від 06 березня 2008 р. № 137-VI.

В межах дослідження, виявлено, що досвід нашої країни щодо застосування принципів ведення гібридної війни та виявлення, усунення гібридних загроз є неоціненним. У більш широкому розумінні, наявність стратегічних комунікацій могла б забезпечити збереження єдності країни та нейтралізацію спроб зовнішнього агресора спровокувати масові протести, соціальні повстання та внутрішні протистояння за наявності великої кількості внутрішньо переміщених осіб. 
3 іншого боку, Україна могла б домагатися від Брюсселя залучення iї до процесів формування європейської безпекової політики 3 правом дорадчого голосу, (що передбачається Угодою про асоціацію). Це сприяло б інтеграції України до системи прийняття політичних рішень $Є С$, збільшило б іiі відповідальність за європейську безпеку та стало б важливим кроком на шляху інтеграції нашої країни до Європейського Союзу.

Ключові слова: механізми державного управління, операції Європейського Союзу із врегулювання криз, принципи ведення гібридної війни, стійкість та безпека України.

Murashko Vitaliy Sergeevich, Senior Lecturer of the Department of Public Administration, Postgraduate, Interregional Academy of Personnel Management, 03039, Kiev, st. Frometovskaya, 2, tel.: 06349531 43, e-mail: murashko.vitalii1981@gmail.com, https//orcid.org/0000-0002-8668-2043

\section{Transformation of the mission of Ukraine and their key directions in shaping the architecture of the modern system of ensuring European security}

Abstract: This article is intended to formulate a list of key areas for the transformation of the mission of Ukraine in shaping the architecture of the modern system of ensuring European security. To the problems of this issue, their scientific searches related and fluent both government executives and scientists from other industry sciences. However, directly, they did not study this issue, which indicates its current actualization.

It was determined that to enter the European community without qualitative and significant changes in the domestic political and legal fields, Ukraine has very few chances to fully. Also, they are necessary in domestic legislation on the creation of effective anti-corruption mechanisms, the development of a radical security reform, military system and the like. Since this is a long process that requires significant investment and time, the study suggests that it is almost impossible to restore the state's defense in a short time.

It should be understood that by participating in the work of international collective security organizations, military security and defense can be strengthened. Despite this, Ukraine began its course on European integration in the field of security and defense with the signing on 13 of June 2005 of the Agreement, which was ratified by the Law of Ukraine from 06 of March 2008 No. 137-VI, between the European Union and Ukraine on determining a common scheme for Ukraine's participation in European Union operations crisis management.

As part of the study, it was revealed that the experience of our country is invaluable in applying the principles of hybrid warfare and in identifying and 
eliminating hybrid threats. In a broader sense, the availability of strategic communications could ensure the preservation of the unity of the country and the neutralization of attempts by an external aggressor to provoke mass protests, social uprisings and internal confrontations in the presence of a large number of internally displaced persons.

On the other hand, to the processes of formation of European security with the right of deliberative vote, (which is assumed by the Association Agreement) Ukraine could seek from Brussels to attract it. This would facilitate Ukraine's integration into the EU political decision-making system, increase its responsibility for European security and become an important step towards the integration of our country into the European Union.

Keywords: government administration mechanisms, European Union crisis management operations, hybrid warfare principles, stability and security of Ukraine.

Постановка проблеми. Сьогодні, гостро постало питання глобального характеру тих загроз, з якими стикається сучасна система забезпечення європейської безпеки. Враховуючи помітне зростання «асиметричних» небезпек міжнародній безпеці (збільшення ймовірного масштабу потенційних збитків від голоду, хвороб, природних стихій, техногенних катастроф, війн), а, також, набуттям ними гнучкої «диверсифікованої» \ транскордонної природи, провідні міжнародні «гравці», насамперед, Європейський Союз та НАТО намагаються оптимізувати інституційне співробітництво у системі національної безпеки у трансатлантичному просторі.

Така оптимізація стосується розробки цілісної «методології взаємодії та протидії» щодо процесу політичної, організаційної та технологічної модернізацій сучасної системи безпеки. У рамках даного процесу, наша країна не може залишатися осторонь процесів формування сучасної європейської (або трансатлантичної) системи безпеки [1, с. 100].

Найважливішою проблемою зовнішньої політики України, яка, поряд 3 тим, є однією з найбільших у Свропі, з історико-географічної точки зору, є неналежне забезпечення рівня національної та регіональної безпек. У політичній сфері, Україною оголошено курс на інтеграцію з євроатлантичними структурами. Основними іiі партнерами є США та Європейський Союз, 3 якими, у 2014 році, була підписана Угода про асоціацію [2].

Питання національної безпеки та забезпечення розвитку ії складових $\epsilon$ пріоритетним у системі державної політики. Тому, інтеграція до європейських та світових спільнот, міжнародних структур безпеки стала головним пріоритетом для розвитку України. При цьому, Україні потрібен власний простір у таких спільнотах, який би гарантував ій стабільність, безпеку та сталий розвиток. Однак, виникає питання, чи відповідають національні структури безпеки рівню забезпеченості та розвитку структур ЄС? 
Аналіз останніх досліджень та публікацій. До проблематики зазначеного питання суміжно та побіжно звертали свої наукові пошуки такі вчені як: Власюк О. С., Красівський О. Я., Мосейко А. Г., Труш О. О., Романенко Є.О. та інші. Вагомий теоретичний внесок у питання сучасної системи забезпечення європейської безпеки здійснив Ситник Г.П. Однак, безпосередньо обрану нами тематику зазначені вчені не вивчали, що свідчить про іiї сучасну актуалізацію.

Мета статті - розглянути перелік ключових напрямів трансформації місії України у формуванні архітектури сучасної системи забезпечення європейської безпеки.

Виклад основного матеріалу. На мою думку, Україна має дуже мало шансів повноцінно увійти у європейське співтовариство без якісних та суттєвих змін у внутрішньому політичному та правовому полях. Також, необхідні зміни у вітчизняному законодавстві з питань створення ефективних механізмів протидії корупції, радикальна реформа безпеки, військової системи тощо. Слід зазначити, що Україна вже зробила деякі успішні кроки на шляху подолання цих проблем, але більшість із них зупинилися на півдорозі [3, с.1].

Фундаментальні національні інтереси України щодо трансформація іiі місії у формуванні архітектури сучасної системи забезпечення європейської безпеки представлені на Рис. 1.

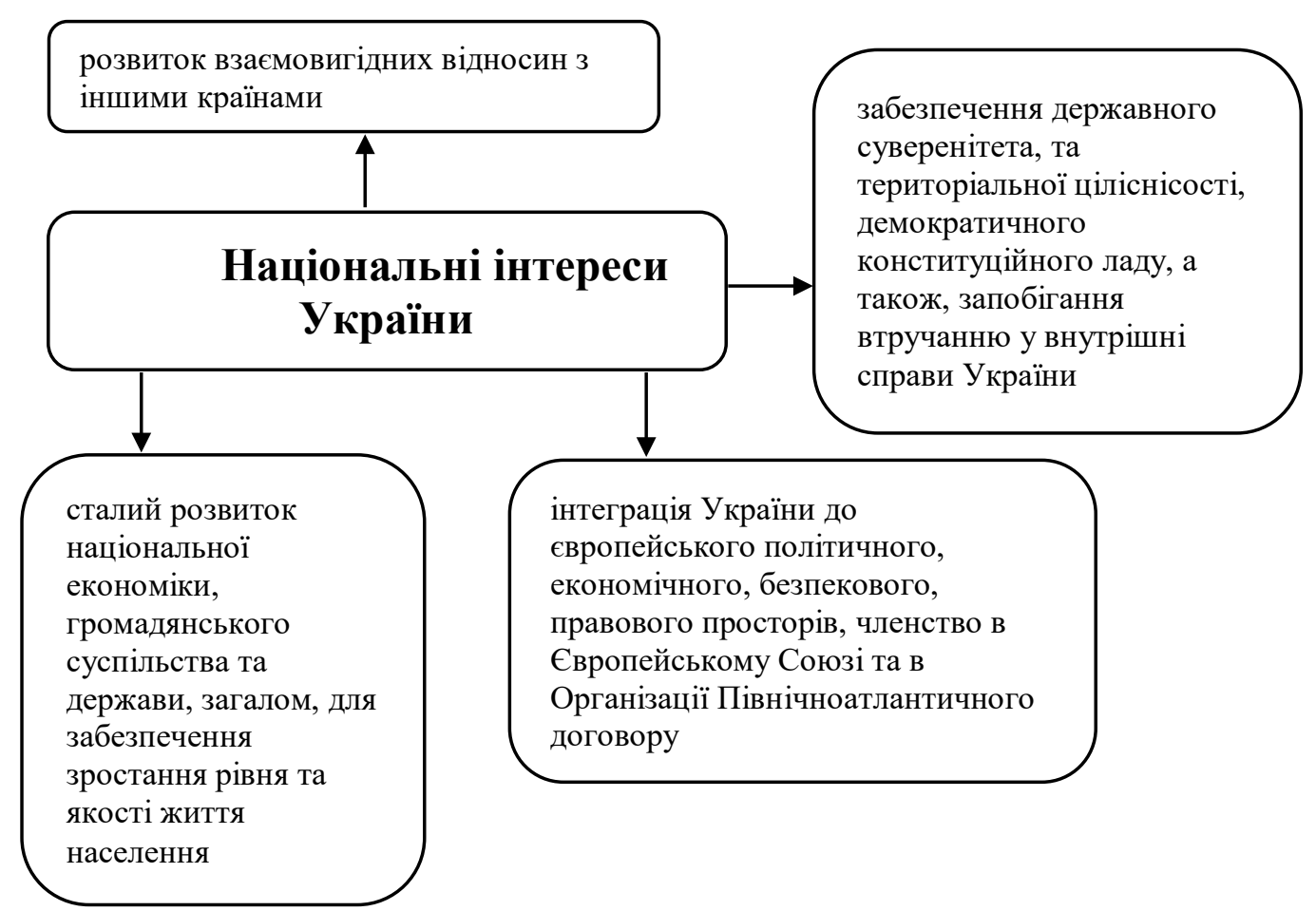

Рис. 1 Національні інтереси України щодо трансформація іiі місії у формуванні архітектури сучасної системи забезпечення європейської безпеки 
Тобто, враховуючи геополітичну та внутрішню ситуації в Україні, діяльність державних органів має бути зосереджена у наступних напрямах [4, c. 47-48]:

- прогнозування, своєчасне виявлення, запобігання та нейтралізація зовнішніх та внутрішніх загроз національній безпеці;

- захист суверенітету та територіальної цілісності України, безпеки держави в іiі прикордонному просторі;

- підвищення рівня економічної стабільності країни;

- забезпечення особистої безпеки, конституційних прав і свобод людини i громадянина;

- викорінення корупційних злочинів;

- вдосконалення системи державної влади, зміцнення правопорядку та підвищення рівня соціально-політичної стабільності суспільства;

- зміцнення позицій України у світі шляхом підтримки на належному рівні iii оборонного потенціалу;

- кардинальне поліпшення екологічної ситуації та ін.

3 метою реалізації зазначених напрямів трансформація місії України у формуванні архітектури сучасної системи забезпечення європейської безпеки була затверджена Стратегія національної безпеки України, однією з цілей якої визначено забезпечення інтеграції України до Свропейського Союзу та створення умов для вступу до НАТО [5].

На мій погляд, донедавна, в історії розвитку України питання безпеки та оборони не були пріоритетними для держави. Реформа Збройних Сил України лише передбачала зменшення їх чисельності та фактичне знищення, не формуючи, при цьому, оптимальної структури.

Однак, слід розуміти, що відновити обороноздатність держави за короткий термін практично неможливо, оскільки, це тривалий процес, який потребує значних інвестицій та часу. Військову безпеку та оборону можна посилити, беручи участь у роботі міжнародних організацій колективної безпеки [6]. Зважаючи на це, у сфері безпеки та оборонної політики курс на європейську інтеграцію Україна розпочала 3 підписання 13 червня 2005 р. Угоди між Свропейським Союзом і Україною про визначення загальної схеми участі України в операціях Свропейського Союзу із врегулювання криз, що ратифікована Законом України від 06 березня 2008 р. № 137-VI [7].

Угода визначає порядок прийняття рішень та загальні умови для проведення Україною цивільних та військових операцій 3 управління кризовими ситуаціями у ЄС. Також, Угодою планувалося визначити загальну схему участі країни, а не окремо для кожної відповідної операції.

Україна співпрацює з Європейським Союзом у галузі глобальної та регіональної безпек відповідно до двосторонніх та багатосторонніх угод, зокрема, у рамках таких регіональних ініціатив $С С$ як Східне партнерство та Чорноморська синергія, а, також, у форматі Свропейської політики сусідства. 
Найважливішим напрямом такої взаємодії $\epsilon$ співпраця щодо протидії «асиметричним» загрозам глобальній та регіональній безпекам у різних сферах розвитку суспільства. (див. Табл. 1).

\section{Напрями співпраці України та ЄС в сфері безпеки}

\begin{tabular}{|c|c|}
\hline Напрям співпраці & Коротка характеристика \\
\hline $\begin{array}{l}\text { Участь } \quad y \\
\text { миротворчих } \\
\text { операціях } Є С\end{array}$ & $\begin{array}{l}\text { Незважаючи на укладення Угоди про визначення } \\
\text { загальної схеми участі України в операціях } \\
\text { Свропейського Союзу із врегулювання кризових } \\
\text { ситуацій та рамкової Угоди про безпекові } \\
\text { процедури, характер взаємодії все ще занадто } \\
\text { слабкий, щоб говорити про конкретні вигоди в галузі } \\
\text { управління кризами або асиметричними викликами, } \\
\text { загрозами міжнародній безпеці. Насправді, єдиним } \\
\text { конкретним результатом співпраці є участь України } \\
\text { у Поліцейській Місії Свропейського Союзу у Боснії } \\
\text { і Герцеговині. }\end{array}$ \\
\hline $\begin{array}{lr}\text { Співробітництво } & 3 \\
\text { СС в рамках заходів } \\
\text { щзодо } \\
\text { нерозповсюдженням } \\
\text { зброї } & \text { масового } \\
\text { ураження } & \text { та } \\
\text { контроль } & \text { над } \\
\text { звичайними } & \\
\text { озброєннями }\end{array}$ & $\begin{array}{l}\text { Вживаються заходи щодо поглиблення співпраці } \\
\text { України з Європолом у цій галузі для поглиблення } \\
\text { взаємодії } 3 \text { центральними органами виконавчої } \\
\text { влади (ключова роль відводиться Міністерству } \\
\text { внутрішніх справ України, яке має координувати } \\
\text { взаємодію між окремими та виконавчими органами } \\
\text { та структурами Європолу щодо протидії сучасним } \\
\text { викликам та загрозам). Реалізується Угода про } \\
\text { стратегічне співробітництво між Україною та } \\
\text { Європолом [8]. }\end{array}$ \\
\hline $\begin{array}{l}\text { Взаємодія з питань } \\
\text { врегулювання } \\
\text { конфліктів у регіоні } \\
\text { найближчого } \\
\text { оточення Украӥни } \\
\text { та } \\
\text { постконфліктного } \\
\text { будівництва }\end{array}$ & $\begin{array}{l}\text { Важливим напрямом співпраці між Україною та ЄС } \\
\text { у сфері прикордонно-митних питань є діяльність } \\
\text { Місії Європейської Комісії з надання допомоги у } \\
\text { питаннях кордону Україні та Республіці Молдова } \\
\text { (EUBAM) [9]. }\end{array}$ \\
\hline $\begin{array}{l}\text { Співпрацъя з проблем } \\
\text { боротьби } \\
\text { нелегальною } \\
\text { міграцією }\end{array}$ & $\begin{array}{l}\text { У сфері управління кордонами та міграційними } \\
\text { процессами діє Робоча угода про встановлення } \\
\text { оперативного співробітництва між Державною } \\
\text { прикордонною службою України та Свропейським }\end{array}$ \\
\hline
\end{tabular}




\begin{tabular}{|c|c|}
\hline & 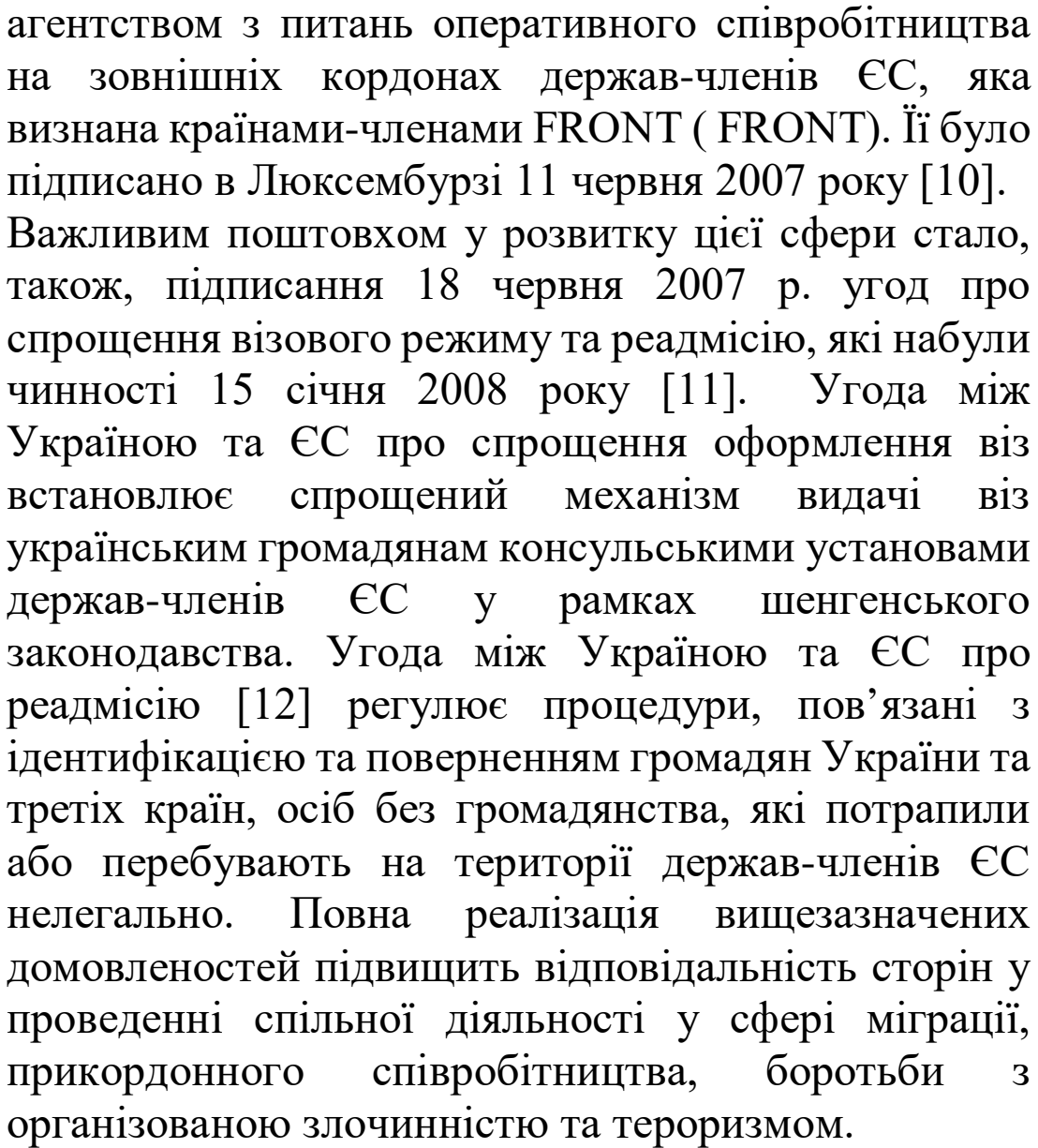 \\
\hline $\begin{array}{l}\text { Взаємодія з проблем } \\
\text { боротьби } \\
\text { незаконним обігом } \\
\text { наркотичних } \\
\text { психотропних } \\
\text { речовин }\end{array}$ & $\begin{array}{l}\text { Вживаються заходи для налагодження контактів між } \\
\text { Міністерством охорони здоров’я України та } \\
\text { Лісабонським моніторинговим Центром ЄС з питань } \\
\text { наркотиків та наркотичної залежності [13]. Разом } 3 \\
\text { цим, відбувається регулярний діалог у сфері протидії } \\
\text { нелегальному обігу наркотиків у форматі Україна- } \\
\text { Трійка СС. }\end{array}$ \\
\hline
\end{tabular}

Таким чином, незважаючи на відсутність консенсусу та бурхливі дебати щодо подальшого стратегічного співробітництва, СС демонструє готовність працювати для розвитку та вдосконалення обороноздатності, поліпшення координації та використання військових технологій. На цьому тлі, співпраця між ЄС та Україною у боротьбі з асиметричними загрозами глобальній та регіональній безпекам залишається однобічною. Україна намагається брати участь у всіх запропонованих СС заходах з підтримання миру, безпеки та виконувати домовленості, в той час як ЄС виставляє багато умов.

Насправді, в Україні дозволено реалізовувати лише ті проекти, які вважаються доцільними. Але у майбутньому ЄС планує направити свої військові миротворчі контингенти в ті регіони, де вже є українські миротворці. 
Цілком ймовірно, що Європейський Союз залучить Україну до стратегічних повітряних перевезень, у рамках миротворчих та антитерористичних операцій.

У зв’язку з цим для України важливо налагодити співпрацю українських військових експертів з Свропейським оборонним агентством та Військовим штабом Європейського Союзу. На мій погляд, доцільно запропонувати $Є С$ створити нову програму партнерства з третіми країнами Спільної європейської політики у сфері безпеки та оброни, яка стала б важливим аспектом у розвитку діалогу поряд із створенням зони вільної торгівлі, спрощенням процедур оформлення віз тощо.

Рішенням Ради національної безпеки і оборони України «Про участь Збройних Сил України у багатонаціональних військових формуваннях високої готовності» від 21 квітня 2011 р., що було уведене в дію Указом Президента України від 21 квітня 2011 р. № 492/2011 [14], визнається доцільною участь Збройних Сил України у багатонаціональних військових формуваннях високої готовності .

За Угодою про асоціацію між Україною, 3 однієї сторони, та Свропейським Союзом, Свропейським співтовариством з атомної енергії і їхніми державами-членами, 3 іншої сторони [15], що ратифікована Законом України від 16 вересня 2014 р. № 1678-VII [16], сторони активізують практичну співпрацю 3 питань запобігання конфліктам та управління кризовими ситуаціями, зокрема, для посилення участі України в цивільних та військових операціях, а, також, у відповідній підготовці та навчанні щодо їх проведення [17, с. 199-201].

Слід зазначити, що Угода про асоціацію не містить норм щодо надання підтримки Україні, зокрема, військової у разі будь-якого збройного конфлікту чи агресії проти неї з боку інших держав. Це тому, що механізм колективної безпеки СС застосовується лише до країн-членів. Однак, це не дає підстав стверджувати, що, в нинішніх умовах, в Україні не існує адекватного рівня захисту національних інтересів та цінностей. Оскільки, з одного боку, вона має здійснювати власну самооборону, а з іншого $\square$ отримує міжнародну підтримку від $€ C$, в тому числі. матеріальні, технічні, організаційні, консультативні заходи тощо.

Водночас, Угода про асоціацію не покладає жодних юридичних зобов'язань щодо членства України в СС. Ми можемо підтвердити дане твердження положенням преамбули цієї Угоди, де зазначено, що вона не надає гарантій щодо перспектив трансформації відносин Україна-ЄС. Тобто, мова йде про те, що Україна не набуває членства в СС, а отже, і у сфері Свропейської політики безпеки i оборони. Однак, Угода розширює сферу координації зовнішньої політики України та СС з питань міжнародних відносин, що становлять спільний інтерес. Крім того, ряд положень Угоди вказує на те, що Україна може вільно розвивати власні політичні позиції. «Крапка» у іiі 
формуванні була поставлена цього року шляхом внесення змін до Конституції щодо вектора розвитку України у напрямі інтеграції до СС та НАТО.

Крім того, слід зазначити, що реалізація інституційного механізму співробітництва між Україною та СС у сфері безпеки має базуватися на принципі консенсусу. Це дозволяє враховувати інтереси обох сторін при прийнятті відповідних рішень та виключає можливість прийняття рішень всупереч позиції України.

На підставі цього, вбачається за доцільне систематизувати організаційні форми міжнародного співробітництва України й СС у сфері безпеки (див.

Рис.2).

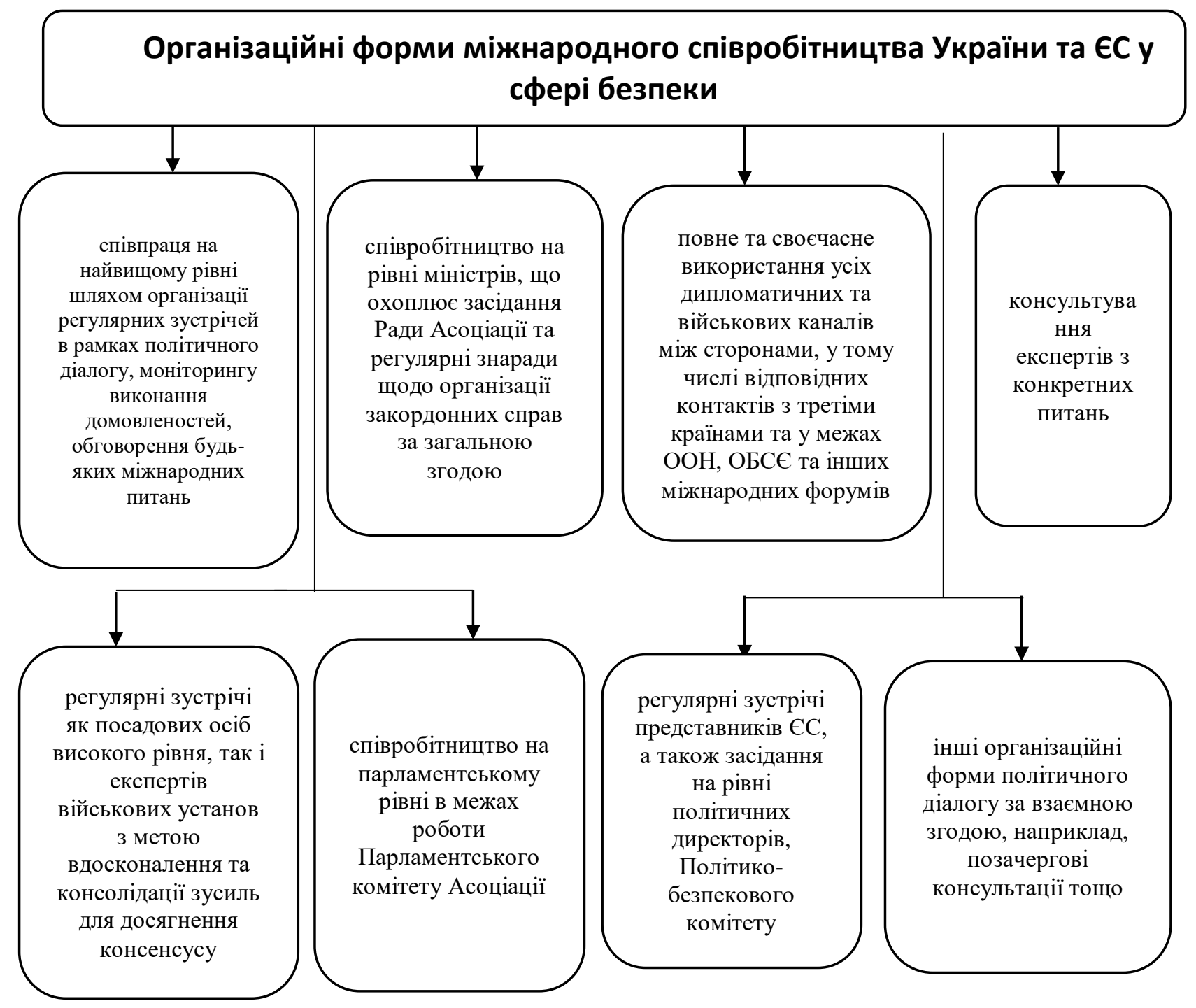

Рис. 2 Організаційні форми міжнародного співробітництва України

Зокрема, 19 вересня 2014 р. Міністром оборони України В. Гелетеєм у Варшаві підписана угода з міністрами оборони Литви та Польщі про створення спільного литовсько-польсько-українського військового підрозділу 
«ЛитПолУкрбриг» [18]. Це був один з найважливіших кроків України щодо модернізації збройних сил України та зміцнення співробітництва з СС.

У 2015 р. Кабінет Міністрів України провів комплексний огляд сектора безпеки і оборони України, за результатами якого, зокрема, було прийнято Воєнну доктрину України, затверджену Указом Президента України від 24 вересня 2015 р. № 555/2015 [19], та Стратегію національної безпеки України, затверджену Указом Президента України від 26 травня 2015 р.№ 287/2015 [20].

Ці підзаконні акти становлять основу для розвитку пріоритетів гарантування національної безпеки України у військовій сфері та спрямовані на максимальне адаптацію обороноздатності України до стандартів СС та НАТО. Пріоритетним національним інтересом України у сфері зовнішньої політики $є$ розвиток та подальше поглиблення відносин між стратегічним партнерством України 3 Організацією Північноатлантичного договору (HATO).

Висновки. У аспекті вищерозглянутих напрямів трансформації місії України у формуванні архітектури сучасної системи забезпечення європейської безпеки, варто зазначити, що сьогодні, наша країна бере участь у військових, цивільних операціях та місіях $\mathrm{CC}$, у реалізації ініціатив щодо формування бойової тактичної групи Європейського Союзу, забезпечує власну транспортну авіацію для іiі використання в інтересах Європейського Союзу.

Наочним прикладом такої співпраці є участь України у Вишеградській бойовій тактичній групі у 2019 р. Крім того, у першій половині 2016 року, підрозділи Збройних сил взяли участь у чергуванні тактичної бойової команди ЄС «Хелброк».

У разі створення «оборонного союзу $Є С$ »країна має потенційні перспективи приєднатися до нього як до партнера. Зважаючи на те, що одна із складових концепції «оборонного союзу ЄС» передбачає створення спільного оборонно-промислового комплексу, Україна могла б тут стати вагомою.

Значення потенційного внеску України формується на основі ії практичного досвіду протягом понад трьох років війни 3 російськими військами та підтримуваними Росією сепаратистськими угрупованнями на сході України, а, також, на основі наявної оборонно-промислової бази в різних галузях - від авіації та суднобудування до останніх технічних розробок у сфері цивільного захисту.

Досвід нашої країни щодо застосування принципів ведення гібридної війни та виявлення, усунення гібридних загроз $є$ неоціненним. У більш широкому розумінні, наявність стратегічних комунікацій могла б забезпечити збереження єдності країни та нейтралізацію спроб зовнішнього агресора спровокувати масові протести, соціальні повстання та внутрішні протистояння за наявності великої кількості внутрішньо переміщених осіб [21].

3 іншого боку, Україна могла б домагатися від Брюсселя залучення іiї до процесів формування європейської безпекової політики 3 правом дорадчого 
голосу, (що передбачається Угодою про асоціацію). Це сприяло б інтеграції України до системи прийняття політичних рішень $Є С$, збільшило б іiі відповідальність за європейську безпеку та стало б важливим кроком на шляху інтеграції нашої країни до Свропейського Союзу.

Для України розвиток автономних європейських оборонних структур відкриває можливість для подальшого поглиблення співпраці з ЄС та паралельного розширення оборонних можливостей. На мою думку, основними напрямами такої співпраці $є$ взаємодія України та $Є С$ у міжнародному та регіональному вимірах задля спільної безпеки; надання допомоги ЄС у зміцненні стійкості та безпеки України. Існує, також, перспектива приєднання України як партнера до «оборонного союзу ЄС», у разі його створення, зокрема, зробити внесок у розвиток спільного оборонно-промислового комплексу, формування структур для боротьби з гібридними загрозами і так далі.

\section{Лimepamypa:}

1. Власюк О. С. Національна безпека України: еволюція проблем внутрішньої політики: Вибр. наук. праці / О. С. Власюк. - К. : НІСД, 2016. - С.528 с.100

2. УГОДА ПРО АСОЦІАЦІЮ між Україною, з однієї сторони, та Європейським Союзом, Свропейським співтовариством з атомної енергії і їхніми державами-членами, 3 іншої сторони, Документ 984_011, поточна редакція — Редакція від 30.11.2015 https://zakon.rada.gov.ua/laws/show/984_011

3. Красівський О. Я. Система безпеки СС в контексті українського вибору [Електронний ресурс] / О. Я. Красівський, Д. О. Красівський. // Державно-управлінські студіï. - 2017. - № 2.C.5 с.1 - Режим доступу: http://nbuv.gov.ua/UJRN/deruprs_2017_2_5

4. Мосейко А. Г. Національна безпека України як об'єкт публічного адміністрування. - С. 42-52. Вісник Луганського державного університету внутрішніх справ імені Е. О. Дідоренка Науково-теоретичний журнал Випуск 2 (86) Сєвєродонецьк 2019 С. 339 с. 47-48

5. Стратегія національної безпеки України Документ n0008525-15, чинний, поточна редакція - Введення в дію від 29.05.2015 https://zakon.rada.gov.ua/laws/show/n0008525-15

6. Труш О. О. Історико-правові засади європейської політики безпеки й оборони / O. О. Труш, Є. М. Нікіпєлова // Теорія та практика державного управління. - 2016. - Вип. 3. - С. 30-37. - Режим доступу: http://nbuv.gov.ua/UJRN/Tpdu_2016_3_7

7. Закон України «Про ратифікацію Угоди між Свропейським Союзом і Україною про визначення загальної схеми участі України в операціях Європейського Союзу із врегулюванням криз» Документ 137-VI, чинний, поточна редакція - Прийняття від 06.03.2008 https://zakon.rada.gov.ua/laws/show/ru/137-17?lang=uk

8. Угода між Україною та Європейським поліцейським офісом про оперативне та стратегічне співробітництво. Документ 984_001-16, чинний, поточна редакція Ратифікація від 12.07.2017 https://zakon.rada.gov.ua/laws/show/984_001-16

9. Джерело: EUBAM http://eubam.org/ua/

10. Робоча домовленість щодо встановлення оперативного співробітництва між Адміністрацією Державної прикордонної служби України I Європейською Агенцією управління оперативним співробітництвом на зовнішніх кордонах держав-членів Європейського Союзу (фронтекс) https://refdb.ru/look/2996262.html

11. Свропейська Агенція 3 прикордонної та берегової охорони (FRONTEX) https://frontex.europa.eu/ 
12. Угода між Україною та Європейським Співтовариством про спрощення оформлення віз Документ 994_850, чинний, поточна редакція — Редакція від 23.07.2012, https://zakon.rada.gov.ua/laws/show/994_850

13. Про ратифікацію Угоди між Україною та Свропейським Співтовариством про спрощення оформлення віз. Документ 117-VI, чинний, поточна редакція - Прийняття від 15.01.2008

https://zakon.rada.gov.ua/laws/show/117-17

14. Указ ПУ Про рішення Ради національної безпеки і оборони України від 21 квітня 2011 року "Про участь Збройних Сил України у багатонаціональних військових формуваннях високої готовності" Документ 492/2011, чинний, поточна редакція Прийняття від 21.04.2011 https://zakon.rada.gov.ua/laws/show/492/2011

15. УГОДА ПРО АСОЦІАЦІЮ між Україною, з однієї сторони, та Європейським Союзом, Свропейським співтовариством з атомної енергії і їхніми державами-членами, 3 іншої сторони, Документ 984_011, поточна редакція - Редакція від 30.11.2015 https://zakon.rada.gov.ua/laws/show/984_011

16. Про ратифікацію Угоди про асоціацію між Україною, 3 однієї сторони, та Європейським Союзом, Європейським співтовариством з атомної енергії і їхніми державами членами, з іншої сторони Документ 1678-VII, чинний, поточна редакція - Прийняття від 16.09.2014 https://zakon.rada.gov.ua/laws/show/1678-18\#n2

17. Нікіпєлова Є.М. Державне управління безпековою політикою Республіки Польща: досвід для України. - Дисертація на здобуття наукового ступеня кандидата наук 3 державного управління за спеціальністю 25.00.05 - державне управління у сфері державної безпеки та охорони громадського порядку. - Національний університет цивільного захисту України. - Харків, 2019. 286 с.199-201

18. Міністерство оборони України Підписано Угоду щодо створення спільної

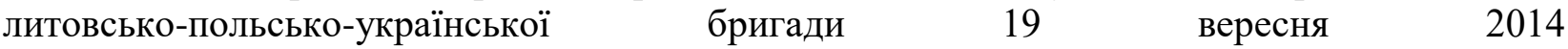
http://www.mil.gov.ua/news/2014/09/19/pidpisano-ugodu-shhodo-stvorennya-spilnoi-litovskopolsko-ukrainskoi-brigadi/

19. Про рішення Ради національної безпеки і оборони України від 2 вересня 2015 року "Про нову редакцію Воєнної доктрини України" Документ 555/2015, чинний, поточна редакція - Прийняття від 24.09.2015 https://zakon.rada.gov.ua/laws/show/555/2015

20. Стратегія національної безпеки України Документ n0008525-15, чинний, поточна редакція - Введення в дію від 29.05.2015 https://zakon.rada.gov.ua/laws/show/n0008525-15

21. Romanenko E., Zhukova I.V. Peculiarities of cooperation of the European Union in the framework of partnership civil society development programs. Public management . 2020. -№ 2 (22) - March 2020. - pp. 191-201.

\section{References:}

1. Vlasiuk, O.S. (2016). Natsionalna bezpeka Ukrainy: evoliutsiia problem vnutrishnoi polityky [National Security of Ukraine: The Evolution of Domestic Policy Issues]. Kyiv: NISD [in Ukrainian].

2. Uhoda pro asotsiatsiiu mizh Ukrainoiu, z odniiei storony, ta Yevropeiskym Soiuzom, Yevropeiskym spivtovarystvom $\mathrm{z}$ atomnoi enerhii i yikhnimy derzhavamy-chlenamy : vid 16.09.2014, № 1678-VII [Association agreement between Ukraine, of the one part, and the European Union, the European Atomic Energy Community and their Member States, of the other part from 16.09.2014, № 1678-VII]. (n.d.). zakon.rada.gov.ua. Retrieved from https://zakon.rada.gov.ua/laws/show/984_011 [in Ukrainian].

3. Krasivskyi, O.Ya., Krasivskyi, D.O. (2017). Systema bezpeky YeS v konteksti ukrainskoho vyboru [The EU Security System in the Context of Ukrainian Choice]. Derzhavno- 
upravlinski studii - $\quad$ Public-administrative studios, 2. $\quad$ Retrieved from http://nbuv.gov.ua/UJRN/deruprs_2017_2_5 [in Ukrainian].

4. Moseiko, A.H. (2019). Natsionalna bezpeka Ukrainy yak obiekt publichnoho administruvannia [National Security of Ukraine as an Object of Public Administration]. Visnyk Luhanskoho derzhavnoho universytetu vnutrishnikh sprav imeni E. O. Didorenka - Bulletin of Luhansk State University of Internal Affairs named after E. Didorenko, 2(86), 42-52 [in Ukrainian].

5. Rishennia rady natsionalnoi bezpeky i oborony ukrainy "Pro Stratehiiu natsionalnoi bezpeky Ukrainy" : vid 6 travnia 2015 roku [Decision of the national security \& defense council of Ukraine "On the National Security Strategy of Ukraine" of May 6, 2015]. (n.d.). zakon.rada.gov.ua. Retrieved from https://zakon.rada.gov.ua/laws/show/n0008525-15 [in Ukrainian].

6. Trush, O.O., Nikipielova, Ye.M. (2016). Istoryko-pravovi zasady yevropeiskoi polityky bezpeky y oborony [Historical and legal foundations of the European security and defense policy]. Teoriia ta praktyka derzhavnoho upravlinnia - Theory and practice of public administration, 3, 30-37. Retrieved from http://nbuv.gov.ua/UJRN/Tpdu_2016_3_7 [in Ukrainian].

7. Zakon Ukrainy «Pro ratyfikatsiiu Uhody mizh Yevropeiskym Soiuzom i Ukrainoiu pro vyznachennia zahalnoi skhemy uchasti Ukrainy $\mathrm{v}$ operatsiiakh Yevropeiskoho Soiuzu iz vrehuliuvanniam kryz» : vid 6 bereznia 2008 roku, № 137-VI [Law of Ukraine “On ratification of the Agreement between the European Union and Ukraine on determining the general scheme of participation of Ukraine in the European Union crisis management operations” from 06.03.2008, № 137-VI]. (n.d.). zakon.rada.gov.ua. Retrieved from https://zakon.rada.gov.ua/laws/show/ru/137-17?lang=uk [in Ukrainian].

8. Uhoda mizh Ukrainoiu ta Yevropeiskym politseiskym ofisom pro operatyvne ta stratehichne spivrobitnytstvo : vid 12.07.2017, № 2129-VIII [Agreement between Ukraine and the European Police Office on operational and strategic cooperation from 12.07.2017, № 2129-VIII]. (n.d.). zakon.rada.gov.ua. Retrieved from https://zakon.rada.gov.ua/laws/show/984_001-16 [in Ukrainian].

9. Sait EUBAM [Site of EUBAM]. eubam.org. Retrieved from http://eubam.org/ua/ [in Ukrainian].

10. Robocha domovlenist shchodo vstanovlennia operatyvnoho spivrobitnytstva mizh Administratsiieiu Derzhavnoi prykordonnoi sluzhby Ukrainy I Yevropeiskoiu Ahentsiieiu upravlinnia operatyvnym spivrobitnytstvom na zovnishnikh kordonakh derzhav-chleniv Yevropeiskoho Soiuzu (fronteks) [Working arrangement to establish operational cooperation between the State Border Guard Service of Ukraine and the European Agency for the Management of Operational Cooperation at the External Borders of the Member States of the European Union (Frontex)]. (n.d.). refdb.ru. Retrieved from https://refdb.ru/look/2996262.html [in Ukrainian].

11. Sait Yevropeiskoi Ahentsii z prykordonnoi ta berehovoi okhorony (FRONTEX) [Site of European Border and Coast Guard Agency (FRONTEX)]. frontex.europa.eu. Retrieved from ttps://frontex.europa.eu/ [in Ukrainian].

12. Uhoda mizh Ukrainoiu ta Yevropeiskym Spivtovarystvom pro sproshchennia oformlennia viz : vid 15.01.2008, № 117-VI [Agreement between Ukraine and the European Community on visa facilitation from 15.01.2008, № 117-VI]. (n.d.). zakon.rada.gov.ua. Retrieved from https://zakon.rada.gov.ua/laws/show/994_850 [in Ukrainian].

13. Pro ratyfikatsiiu Uhody mizh Ukrainoiu ta Yevropeiskym Spivtovarystvom pro sproshchennia oformlennia viz : vid 15.01.2008, № 117-VI [On ratification of the Agreement between Ukraine and the European Community on visa facilitation from 15.01.2008, № 117-VI]. (n.d.). zakon.rada.gov.ua. Retrieved from https://zakon.rada.gov.ua/laws/show/117-17 [in Ukrainian].

14. Ukaz PU Pro rishennia Rady natsionalnoi bezpeky i oborony Ukrainy vid 21 kvitnia 2011 roku "Pro uchast Zbroinykh Syl Ukrainy u bahatonatsionalnykh viiskovykh formuvanniakh vysokoi hotovnosti" : vid 21 kvitnia 2011 roku, № 492/2011 [Decree of the PU on the decision of 
the National Security and Defense Council of Ukraine of 21 April 2011 "On the participation of the Armed Forces of Ukraine in high-level multinational military units" from 21.04.2011, № 492/2011]. (n.d.). zakon.rada.gov.ua. Retrieved from https://zakon.rada.gov.ua/laws/show/492/2011 [in Ukrainian].

15. Uhoda pro asotsiatsiiu mizh Ukrainoiu, z odniiei storony, ta Yevropeiskym Soiuzom, Yevropeiskym spivtovarystvom $\mathrm{z}$ atomnoi enerhii i yikhnimy derzhavamy-chlenamy, $\mathrm{z}$ inshoi storony : vid 16.09.2014, № 1678-VII [Association agreement between Ukraine, of the one part, and the European Union, the European Atomic Energy Community and their Member States, of the other part from 16.09.2014, № 1678-VII]. (n.d.). zakon.rada.gov.ua. Retrieved from https://zakon.rada.gov.ua/laws/show/984_011 [in Ukrainian].

16. Pro ratyfikatsiiu Uhody pro asotsiatsiiu mizh Ukrainoiu, $\mathrm{z}$ odniiei storony, ta Yevropeiskym Soiuzom, Yevropeiskym spivtovarystvom $\mathrm{z}$ atomnoi enerhii i yikhnimy derzhavamy chlenamy, z inshoi storony : vid 16 veresnia 2014 roku № 1678-VII [On ratification of the Association Agreement between Ukraine, of the one part, and the European Union, the European Atomic Energy Community and their Member States, of the other part from 16.09.2014 roku № 1678-VII]. (n.d.). zakon.rada.gov.ua. Retrieved from https://zakon.rada.gov.ua/laws/show/1678-18\#n2 [in Ukrainian].

17. Nikipielova, Ye.M. (2019). Derzhavne upravlinnia bezpekovoiu politykoiu Respubliky Polshcha: dosvid dlia Ukrainy [Public Administration of the Security Policy of the Republic of Poland: Experience for Ukraine]. Candidate's thesis. Kharkiv [in Ukrainian].

18. Ministerstvo oborony Ukrainy Pidpysano Uhodu shchodo stvorennia spilnoi lytovskopolsko-ukrainskoi bryhady [Ministry of Defense of Ukraine Signed an Agreement on Creation of a Joint Lithuanian-Polish-Ukrainian Brigade]. (2014). www.mil.gov.ua. Retrieved from http://www.mil.gov.ua/news/2014/09/19/pidpisano-ugodu-shhodo-stvorennya-spilnoi-litovskopolsko-ukrainskoi-brigadi/ [in Ukrainian].

19. Ukaz Prezydenta Ukrainy "Pro rishennia Rady natsionalnoi bezpeky i oborony Ukrainy vid 2 veresnia 2015 roku "Pro novu redaktsiiu Voiennoi doktryny Ukrainy" : vid 24 veresnia 2015 roku, № 555/2015 [Decree of the President of Ukraine "On the decision of the National Security and Defense Council of Ukraine of September 2, 2015 "On the new version of the Military Doctrine of Ukraine" from 24.09.2015, № 555/2015]. (n.d.). zakon.rada.gov.ua. Retrieved from https://zakon.rada.gov.ua/laws/show/555/2015 [in Ukrainian].

20. Rishennia Rady Natsionalnoi Bezpeky i Oborony Ukrainy "Pro Stratehiiu natsionalnoi bezpeky Ukrainy” : vid 26 travnia 2015 roku, № 287/2015 [Decision of The National Security \& Defense Council of Ukraine "On the National Security Strategy of Ukraine” from 26.05.2015, № 287/2015]. (n.d.). zakon.rada.gov.ua. Retrieved from https://zakon.rada.gov.ua/laws/show/n0008525-15 [in Ukrainian].

21. Romanenko, E., Zhukova I.V. (2020). Peculiarities of cooperation of the European Union in the framework of partnership civil society development programs. Public management, 2(22), 191-201 [in English]. 